\title{
A Community Arts Program for Underserved Children: Getting Things Done and Member Development
}

\author{
Sang-Hie Lee ${ }^{\mathrm{a}^{*}}$ \\ ${ }^{a}$ Professor in Music Medicine and Research, School of Music, College of the Arts, University of South Florida, United States. \\ Received 27 April 2020; Accepted 15 June 2020
}

\begin{abstract}
The Program: The AmeriCorps ArtsUSF program was a federally funded outreach program that provided hands-on arts experience to underserved children in culturally and economically deprived communities in and around a large metropolitan area. The project had two components: Getting Things Done (GTD) and Member Development (MD). Objectives: The goals of GTD were to help improve the communities' self-image, stability, and culture by providing accessible, safe, and affordable cultural activities and programs. The goals of MD were to help the AmeriCorps volunteer artist-teacher members develop an awareness of societal problems, teaching and class management skills, and to become responsible citizens. Methods: GTD goals were measured using a quantitative survey instrument developed for the program. Pre (November) and post (May) data were compared using paired one-tailed t-tests to see if there were significant changes. MD outcomes were summarized from content analysis of member journals. Results: Data showed progress in all measured items, particularly, integrating arts to life, group problem-solving skills, attitude on diversity, and attitude on being-kind-to-each-other. Factor analysis results demonstrated strong connections among arts skills, expression through the arts, art appreciation skills, and integrating arts to life. There was an association among class learning skills, attitude on diversity, and attitude on being kind-to-each-other. Independent problem-solving skills were associated with expressive skills through the arts, integrating arts to life, attitude on diversity, and class learning skills. In the post data, independent problem-solving skills were further related to anti-drug, alcohol, and smoking attitude, and art skills. Members expressed that AmeriCorps ArtsUSF experience provided a life-changing impact on them. Seeing the effects of their input on other, they realized that one way of achieving the American dream was by helping others. Conclusion: The program gave a sense of pride and ownership to the underserved communities, and the experience gave the artist-members the confidence and self-esteem necessary to pursue their own life's goals. Novelty: Federally funded, community-wide supported program with novel program and curriculum. Improvement: The initial phase could be better organized and more affective narratives could be added in the survey instrument.
\end{abstract}

Keywords: Community Arts Program; Americorps Service Program; Integrated Arts Program; Underserved Children; Artist-Member Development; Arts Skills and Attitude on Diversity and Community; Being Nice-To-Each-Other; Self Image.

\section{Introduction}

A report by the National Endowment for the Arts identified specific reasons why arts education is important: Arts education (1) provides young people a sense of civilization; (2) fosters creativity and teaches effective communication; (3) provides tools for critical thinking; and (4) can improve the general learning environment [1]. Studies have shown that the stimuli provided through the arts play in healthy brain development; and that participation in the arts affects positively in the school community, appreciation of cultural differences, and active community service [2]. The National Standards for Arts Education addressed the arts in creating a literate, imaginative, competent, and creative

\footnotetext{
* Corresponding author: slee@usf.edu

do) http://dx.doi.org/10.28991/SciMedJ-2020-0203-4
}

$>$ This is an open access article under the CC-BY license (https://creativecommons.org/licenses/by/4.0/).

(C) Authors retain all copyrights. 
society by providing children with tools to understand the world. ${ }^{2}$ Further, the arts help develop intellectual as well as emotional capacities of the children. Goleman posited, "emotion is...crucial to effective thought, both in making wise decisions and... thinking clearly." [3].

Efforts to lift community culture and people's lives through organized arts programs have been utilized at different parts of the world. A Taiwanese program attempted to enhance community culture through an interactive college arts course [4]. Wagga Wagga Art Gallery (WWAG) in New South Wales, Australia initiated a program in which art educators, indigenous people, and elementary school children were brought together to experience cultural significance and importance of regional indigenous arts. The program had longitudinal effects on the community [5]. Tate Modern, a major London art gallery applied arts-based program for mental health service. Workshops were focused on symbolic and physical aspects, relational and social context, and reflections on relationships between the arts-based program and mental health. They concluded that there were more nuanced understanding in the relationships between arts-based program and mental health [6]. In Koidu City, Sierra Leone, community-based ART program was experimented for $52 \mathrm{HIV}$-infected people and the result was compared with $91 \mathrm{HIV}$-infected persons with normal care. The strategy of this 24-month study included patient-centered comprehensive medical, educational, psychological, social, and economic support. Participants who received community-based ART had significantly higher retention-in-care at 12-month and 24-month check points than those who did not received the ART. Level of adherence to ART principles over 3-month period check was also significantly different between the groups [7].

Several arts programs have been reported from early childhood development to youth intervention programs. A community-based 'play-and-art' program was conducted to provide families of pre-schoolers to develop parenting skills while supporting child's socioemotional development for low-income families [8]; a community arts program for low-income community youth in Tampa Bay area showed improvement in social, psychological, and arts skills [9]. A five-year follow-up study of a Canadian youth arts program indicated that the arts program had long-term effects on skill acquisition, team building, positive staff and youth relationships, positive peer-relationships, and a sense of belonging [10]. A community-based arts and humanities mentoring program linked undergraduate students and children from underserved communities. This interdisciplinary service-learning program taught citizenship and critical pedagogy [11]. Through a literature analysis, Ngo, Lewis, and Leaf demonstrate that community-based arts programs have the capacity to promote teaching and learning practices by engaging the youth to develop academic skills, inquiry, cultural and socio-political consciousness, and social action [12]. Clearly, community-based arts programs have two-pronged benefits: the chidrens' development; and community as well as teacher development.

AmeriCorps ArtsUSF program was created to provide intense, expressive arts activities to children who live in the culturally and economically deprived environment. The program was focused on building children's skills, community awareness and self-esteem and to encourage children to make meaningful connections to the real world and "to generate new insights and to synthesize new relationships between ideas" [13]. The second component of AmeriCorps ArtsUSF goals was to provide the volunteer artist-teachers with in-service job training and lessons in civic service [14].

\section{The Program}

In response to a community-based initiation developed through a year-long collaborative effort among the University of South Florida Fine Arts College and surrounding community constituents in the Tampa Bay area, we developed an integrated arts program and applied for funding from the National Commission on Service [14]. This coalition had concluded that the arts experience taught by trained artists could indeed have impacts on lifting children's self-image and quality of life in these economically and culturally deprived communities. Children's program was focused on both skills and attitude development. The program was designed to help develop hands-on arts skills, arts appreciation skills, skills to express feelings in creative and appropriate ways; and to help improve school performance, social skills, and attitude about anti-drug, alcohol, and smoking, attitudes toward self and community, and being kind-to-each-other. The end goal was to lift the quality of life of culturally disadvantaged children and to increase their knowledge of the diversity of peoples and cultures in the surrounding communities through arts experience. Member Development program was designed to offer the artist-teachers an opportunity to expand their horizon through the concept of volunteerism and to develop a sense of direction in their life. Member training program was focused on interdisciplinary arts approach, solving societal problems through the arts, teaching skills, organizational skills, communication skills, and team-building skills.

The objectives of Getting Things Done were:

(1) Improved hands-on arts skills and self-esteem;

(2) Improved arts appreciation skills;

(3) Improved skills to express feelings in creative and appropriate ways; 
(4) Improved school performance; and

(5) Improved attitude in being kind-to-one-another.

The objectives of Member Development were:

(1) Improved understanding of the interdisciplinary arts approach;

(2) Improved teaching skills;

(3) Improved understanding of societal problems;

(4) Improved skills on solving societal problems through the arts;

(5) Improved organizational skills;

(6) Improved communication skills; and

(7) Improved team-building skills.

The program was offered after-school hours and during summer to some 600 children ages six through 14 at four Boys and Girls Club sites and a Hillsborough County Park and Recreation site. Small classes were taught daily by 24 AmeriCorps volunteer artists who created unique and outstanding arts programs with the intention to touch the lives of the children and their communities. Two full time and two half time AmeriCorp artist members were assigned to teach arts at each site. The Members worked collaboratively with site managers who helped with enrolment and class supervision. The National Commission on Service guidelines required volunteer members to serve eighteen hundred hours for full time and nine hundred hours for half time. The total commitment hours consisted of the time allocated for training, preparation, meetings, reflective journal writing, and assessing children's progress by completing Pre and Post surveys, in addition to class teaching hours. Members were compensated with a minimum living stipend, health insurance, and a scholarship to be used to pay off student loan or for graduate study.

\section{Curriculum}

A curriculum was developed by a group comprised of four USF fine arts faculty members and two external consultants with specialties in dance, music, visual arts, and theatre. This was further refined incorporating inputs from AmeriCorps ArtsUSF members during the first year of the program in 1997-98 [15].Throughout the development of the curriculum, three themes were maintained: (1) integrating the arts; (2) connecting the arts to other disciplines of study; and (3) connecting the arts to life experiences and the real world.

Curriculum modules progressed from focusing on learning about the individual children and their daily lives, to exploring the meaning of arts in our society, culture, and heritage. In Module A, children were encouraged to use language and free movements, collaborate with others towards simple goals in drama, explore the concept of music by gathering sample sounds, and learn photography, painting, and sphere drawing. In Module B, children experienced how to express themselves by creating and sharing their arts. Module $\mathrm{C}$ focused further on the development of the children's self-expression and self-knowledge. They learned skills to express and create their thoughts and feelings into art in small-group settings, which allowed children to develop sense of community and experience the importance of collaboration. By learning to appreciate others' artistic abilities and choices, they learned to recognize their own abilities and choices. In Module D, children took a look at their family background and their community; and explored folklore and tribal rituals through story-telling and drawing. Throughout the Modules, children developed knowledge of the rich and diverse history and culture of their own neighbourhood and surrounding Tampa Bay. Members were encouraged to improvise freely departing from the lessons in the modules.

\section{Evaluation}

\subsection{The Instruments}

A survey instrument, AmeriCorp ArtsUSF Getting Things Done (AAGTD) was developed to evaluate the program impact [16] (see Appendix). Section one of AAGTD contains four dimensions of arts and arts-related skills: (1) arts skills, (2) expressive skills through the arts, (3) arts appreciation skills, and (4) integrating arts to life. Section two has three dimensions of learning skills: (1) class learning skills, (2) independent problem-solving skills, and (3) group problem-solving skills. Section three measures four dimensions of attitude: (1) diversity of culture and people, (2) being kind-to-each-other, (3) anti-drug, alcohol, and smoking, and (4) attitudes about the community. These constructs were operationalized into 40 observable variables using Likert-type scale rating from one to five with five being the highest.

In addition, Prosocial Skills (PSS) for the Child [17] was modified with permission to evaluate social skills development. PSS has five domains: (1) classroom survival skills; (2) skills alternative to aggression; (3) friendship- 
making skills; (4) skills for dealing with feelings; and (5) skills for dealing with stress. The total of 35 variables were rated with Likert-type scale ranging from one to five with five being the highest.

\subsection{Methodology}

Several community-based art teachers were consulted to check for content validity; and the instruments were pilottested to help improve construct validity before setting in print. AmeriCorp ArtsUSF artist members administered the surveys twice: baseline data were collected in November after the initial organizational period of the program; and the year-end data, in May. There were 191 usable surveys that had both pre- and post- datasets. This number was smaller than the total number of children in the program due to the high turn-over between fall and spring terms. November and May data were coordinated to maintain consistency of the students subjects who stayed through both terms. Summer enrolments were unstable due to unstable attendance and therefore were not included in the analysis. November and May scores provided information with longer-term (at least seven months) effects. Paired t-tests were used to compare changes in pre and post data. Factor analysis was performed on both datasets to examine the relationships among the variables and to check for construct validity. Cronbach's alpha was run with both datasets of AAGTD variables to check for reliability of the instrument. High alpha values affirmed reliability of the instrument (alpha estimates range between 0.72 and 0.86 ). Flowchart of the research methodology has presented as below:

\begin{tabular}{|c|c|c|c|c|c|c|}
\hline & Timeframe & Validity & Reliability & Analyses & $\mathbf{N}$ & Age Range \\
\hline $\begin{array}{l}\text { AmeriCorps ArtsUSF } \\
\text { Getting Things Done }\end{array}$ & $\begin{array}{l}9 \text { months } \\
\text { Sept-May }\end{array}$ & $\begin{array}{l}\text { Content validity } \\
\text { Expert consultation } \\
\text { Construct validity } \\
\text { Pilot test } \\
\text { Factor analysis }\end{array}$ & $\begin{array}{l}\text { Cronbach's } \\
\text { alpha }\end{array}$ & $\begin{array}{l}\text { Paired t-test } \\
\text { Factor analysis }\end{array}$ & 191 & $5-14$ \\
\hline $\begin{array}{l}\text { AmeriCorps ArtsUSF } \\
\text { Member Development }\end{array}$ & $\begin{array}{l}9 \text { months } \\
\text { Sept-May }\end{array}$ & $\begin{array}{l}\text { Member training } \\
\text { Request for details }\end{array}$ & $\begin{array}{l}\text { Attention to detail } \\
\text { Cross-check }\end{array}$ & $\begin{array}{l}\text { Content } \\
\text { analysis }\end{array}$ & 24 & $22-63$ \\
\hline
\end{tabular}

Members were informed at the outset that daily journals were required for weekly discussion and for research. Qualitative member journal data were content analysed to capture salient issues, progress patterns, skills development, self-development, and other relationships that had emerged. Careful reading and insightful content analyses were attempted to ensure reliability [18-20].

\section{Results}

\subsection{The Children: Data Description by Age Group and Site}

Table 1 shows, that there were more younger children than older age children with some variations by site: overall, $39 \%$ of children were between ages five to seven; $34 \%$ was ages eight to nine; $25 \%$, ages ten to eleven; and $2 \%$, ages twelve and older.

Table 1. The Children: Data Description by Age Group and Site

\begin{tabular}{cccccccc}
\hline Age group & Dover & Interbay & North Tampa & Salesian & Zonta & Total & $\%$ \\
\hline 5 to 7 & 25 & 2 & 2 & 19 & 26 & 74 & $39 \%$ \\
8 to 9 & 16 & 4 & 12 & 10 & 23 & 65 & $34 \%$ \\
10 to 11 & 8 & 5 & 10 & 14 & 11 & 45 & $25 \%$ \\
12 to 14 & 1 & 1 & - & - & 2 & 4 & $2 \%$ \\
Total & 50 & 12 & 24 & 43 & 62 & 191 & $100 \%$ \\
$\%$ & $26 \%$ & $6 \%$ & $13 \%$ & $22 \%$ & $33 \%$ & $100 \%$ & \\
\hline
\end{tabular}

\subsection{Children's Skills and Attitude Development}

Table 2 shows significant increase in overall arts and learning skills by $18 \%$ ( $\mathrm{p}<.001)$. Specifically, arts skills improved by $17 \%$, expressive skills and appreciation skills, each by $21 \%$, and integrating arts to life skill by $23 \%$. Equally significant improvement is evident in class learning and group problem-solving skills each by $18 \%$ and independent problem-solving skills by $13 \%$. Overall attitude improved by $14 \%$ ( $<<.001)$. Noticeably, attitude on diversity changed positively by 18\%; attitude on being kind-to-each-other, 16\%; anti-drug, alcohol, and smoking by $6 \%$; and attitude regarding the community increased by $13 \%$.

The overall change in prosocial skills $(\mathrm{p}<.001)$ was $13 \%$ : site survival skills improved by $14 \%$; alternate skills to aggression, 15\%; friendship-making skills, 14\%; dealing with feelings, 13\%; and dealing with stress, 10\%. Slightly 
larger standard deviation values in PSS indicated wider spread among individuals in prosocial skills developments than arts skills or attitude in AAGTD.

Table 2. Children's Skills and Attitude Development (N=191)

\begin{tabular}{|c|c|c|c|c|c|c|}
\hline \multicolumn{3}{|c|}{ Number of items } & Pre Score (Sd) & Post Score (Sd) & t score & $\%$ Change \\
\hline \multirow{7}{*}{ 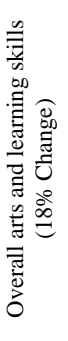 } & Arts skills & 6 & $25.84(4.11)$ & $32.72(4.86)$ & $18.71^{*}$ & $17 \%$ \\
\hline & Expressive skills & 3 & $13.23(2.46)$ & $17.42(2.13)$ & $22.32 *$ & $21 \%$ \\
\hline & Appreciation skills & 4 & $12.01(2.18)$ & $16.25(2.64)$ & $18.52 *$ & $21 \%$ \\
\hline & Integrating arts to life & 7 & $27.21(4.97)$ & $37.24(5.97)$ & $22.19 *$ & $23 \%$ \\
\hline & Class learning skills & 4 & $18.42(3.61)$ & $23.04(3.05)$ & $14.70^{*}$ & $18 \%$ \\
\hline & Group problem-solving skill & 3 & $10.88(2.27)$ & $13.68(2.03)$ & $13.65^{*}$ & $18 \%$ \\
\hline & Independent problem- solving skills & 2 & $10.67(1.71)$ & $12.65(2.10)$ & $10.24 *$ & $13 \%$ \\
\hline \multirow{4}{*}{ 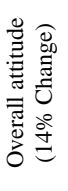 } & Diversity & 3 & $14.75(2.33)$ & $18.46(2.28)$ & $16.96^{*}$ & $18 \%$ \\
\hline & Being kind-to-each-other & 4 & $15.05(2.72)$ & $18.20(2.75)$ & $12.09 *$ & $16 \%$ \\
\hline & Anti-drug, alcohol, and smoking & 2 & $9.47(1.79)$ & $10.42(2.80)$ & $5.71^{*}$ & $6 \%$ \\
\hline & Attitude on community & 2 & $6.45(1.27)$ & $7.83(1.91)$ & $10.11^{*}$ & $13 \%$ \\
\hline \multirow{5}{*}{ 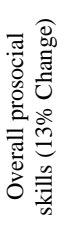 } & Site survival skills & 9 & $33.86(6.98)$ & $40.25(4.56)$ & $12.08 *$ & $14 \%$ \\
\hline & Alternative skills to aggression & 6 & $20.80(6.79)$ & $25.07(4.46)$ & $8.19^{*}$ & $15 \%$ \\
\hline & Friendship-making skills & 8 & $28.43(7.28)$ & $34.78(4.99)$ & $11.64 *$ & $14 \%$ \\
\hline & Dealing with feelings & 6 & $20.25(5.82)$ & $24.19(4.58)$ & $8.75^{*}$ & $13 \%$ \\
\hline & Dealing with stress & 6 & $20.25(8.18)$ & $23.13(6.24)$ & $4.94 *$ & $10 \%$ \\
\hline
\end{tabular}

\subsection{AAGTD Factor Analysis Summary: Relationships among Skills and Attitude Variable}

Factor analysis affirmed construct validity of AAGTD. Factor analysis results gave insights into the underlying relationships among the skills and attitude dimensions. Arts and arts-related skills are grouped together as intended in both pre and post datasets. Arts skills, expressive skills through the arts, arts appreciation skills, and integrating arts to life are factored in factors one and two in pre and post data. We were pleased to observe that class learning skills and independent problem-solving skills were closely tied to attitude on diversity as well as attitude on being kind-to-eachother in the post data. With some variations, both pre and post datasets show close relationships among independent problem-solving skills, anti-drug, alcohol, and smoking attitude, attitude on community, and group problem-solving skills.

Table 3. AAGTD Factor Analysis Summary: Relationships among Skills and Attitude

\begin{tabular}{|c|c|c|}
\hline & Pre (November) & Post (May) \\
\hline Factor one & $\begin{array}{l}\text { Arts skills } \\
\text { Expressive skills through the arts } \\
\text { Integrating arts to life }\end{array}$ & $\begin{array}{l}\text { Arts skills } \\
\text { Expressive skills through the arts } \\
\text { Arts appreciation skills } \\
\text { Integrating arts to life }\end{array}$ \\
\hline Factor two & $\begin{array}{l}\text { Arts appreciation skills } \\
\text { Integrating arts to life }\end{array}$ & $\begin{array}{l}\text { Expressive skills through the arts } \\
\text { Class learning skills } \\
\text { Independent problem-solving skills } \\
\text { Attitude on diversity } \\
\text { Attitude on being kind-to-each-other }\end{array}$ \\
\hline Factor three & $\begin{array}{l}\text { Expressive skills through the arts } \\
\text { Class learning skills } \\
\text { Independent problem-solving skills } \\
\text { Integrating arts to life } \\
\text { Attitude on diversity }\end{array}$ & $\begin{array}{l}\text { Arts skills } \\
\text { Independent problem-solving skills } \\
\text { Anti -drug, alcohol, and smoking attitude }\end{array}$ \\
\hline Factor four & $\begin{array}{l}\text { Attitude on diversity } \\
\text { Attitude on being kind-to-each-other }\end{array}$ & $\begin{array}{l}\text { Class learning skills } \\
\text { Group problem-solving skills }\end{array}$ \\
\hline Factor five & $\begin{array}{l}\text { Anti-drug, alcohol, and smoking attitude } \\
\text { Attitude on community }\end{array}$ & Arts skills \\
\hline Factor six & $\begin{array}{l}\text { Class learning skills } \\
\text { Group problem-solving skills } \\
\text { Attitude on diversity }\end{array}$ & Attitude on being kind-to-each-other \\
\hline
\end{tabular}




\section{Member Development}

\subsection{Member Profile}

Members came from diverse geographical locations, for example, Florida, New York City, Hungary, Philadelphia, with varied artistic talents and training in music, dance, theatre, visual arts, film, and woodworking. The age ranged from 22 to 63 . Members were selected based on their background and commitment to the AmeriCorps' mission on serving the community while developing self. The profiles of artist members shown in Table 4 display a sample of well-trained artists in theatre, cinema studies, painting, poetry, music education, rhythm and movement with varied experiences.

Table 4. Sample Artist Member Profile

\begin{tabular}{|c|c|c|c|}
\hline $\begin{array}{c}\text { Artist } \\
\text { Member }\end{array}$ & Artistic background and training & Relevant work experience & Personal impression \\
\hline $\mathbf{A}$ & $\begin{array}{l}\text { A full-time Member at Interbay Boys and } \\
\text { Girls Club, has a BFA in Theatre from } \\
\text { University of Florida. }\end{array}$ & $\begin{array}{l}\text { She has performed in fifteen plays since } \\
\text { 1997. She learned about the program } \\
\text { through a local newspaper. }\end{array}$ & $\begin{array}{l}\text { I have been wanting to be involved as a } \\
\text { volunteer in some sort of meaningful activity to } \\
\text { enrich the lives of others, as well as my own. }\end{array}$ \\
\hline B & $\begin{array}{l}\text { A full-time volunteer at Philip Shore } \\
\text { Elementary School received a BFA in } \\
\text { Cinema Studies at New York University. }\end{array}$ & $\begin{array}{l}\text { He worked at the Whitney Museum of Art as } \\
\text { a sales associate and at the Museum of } \\
\text { Modern Art as a curatorial assistant in New } \\
\text { York City before moving to Tampa with two } \\
\text { other AmeriCorps ArtsUSF volunteer artists. }\end{array}$ & $\begin{array}{l}\text { Art offers young people a new chance to create } \\
\ldots \text { They may... mold and shape their dreams } \\
\text { [that] may one day be realized as reality. }\end{array}$ \\
\hline $\mathbf{C}$ & $\begin{array}{l}\text { A full-time Member at West Tampa } \\
\text { Boys and Girls Club received a BA in } \\
\text { Painting and a BA in International } \\
\text { Studies in Art History from the } \\
\text { University of South Florida. }\end{array}$ & $\begin{array}{l}\text { A well-established painter in the area, she } \\
\text { had many commissioned works including } \\
\text { several murals in public places in Tampa } \\
\text { and Miami. }\end{array}$ & $\begin{array}{l}\text { She expressed a deep social commitment, and } \\
\text { said that AmeriCorps would "channel her skills } \\
\text { and positive energy in a most beneficial way. }\end{array}$ \\
\hline D & $\begin{array}{l}\text { A second year part-time Member from } \\
\text { Vac, Hungary had been teaching art for } \\
30 \text { years before moving to the United } \\
\text { States six years ago. Already with two } \\
\text { teaching degrees in Upper Primary } \\
\text { Education from Hungary, she continued } \\
\text { her education at Tampa Technical } \\
\text { Institute. }\end{array}$ & $\begin{array}{l}\text { She published many poems and recently } \\
\text { won a Grand Prize for best art display at the } \\
\text { State Fair in Tampa. }\end{array}$ & \\
\hline $\mathbf{E}$ & $\begin{array}{l}\text { A part-time Member at Zonta Boys and } \\
\text { Girls Club, was working on her degree in } \\
\text { Music Education from the University of } \\
\text { South Florida. }\end{array}$ & $\begin{array}{l}\text { Originally from the Bahamas, she was very } \\
\text { involved with the Music Department as a } \\
\text { concert band clarinettist. }\end{array}$ & \\
\hline $\mathbf{F}$ & $\begin{array}{l}\text { A part-time Member who worked as a } \\
\text { floater in rhythm and movement at } \\
\text { several sites, came from Philadelphia. }\end{array}$ & $\begin{array}{l}\text { She was responsible for spearheading a live } \\
\text { performance that dealt with African } \\
\text { American celebrations in the production } \\
\text { "Bring in 'Da Noise, Bring in 'da Funk" } \\
\text { performed at the Tampa Performing Arts } \\
\text { Center. }\end{array}$ & $\begin{array}{l}\text { She participated in many community activities } \\
\text { and believed that we had lost the sense of } \\
\text { community, which was once the focal point of } \\
\text { human existence. }\end{array}$ \\
\hline
\end{tabular}

\subsection{The Experience}

There was an overwhelming sense among members that this was a life-changing experience for many of them. It was an equally eye-opening, heart-warming experience for members as it was for the children as they ventured together in this program. As shown in Table 5, six themes surfaced in the content analysis of member journal: Members felt that the program had helped their growth in Experience, Creativity, Teaching, Culture, Community Awareness and Frustration.

Field trips to Tampa Bay Performing Arts Centre, museums and theatres, and University of South Florida were new experiences for most of the children. Week-to-week work was long and hard for teachers, but seeing the children enjoying and learning through the day-to-day activities gave them wonderful feelings. Many members wrote that the program was "running smoothly" and "projects were flowing." They saw the children "enthusiastic," "full of positive energy," "excited," and "expressive." One member described the dynamics vividly, "The week was long and hard and wonderful. Monday through Thursday, we worked toward the photo contest. I brought my manual camera and showed them how to set the shutter and aperture and how to focus. Each child took about five to ten photos, many of which were excellent. We submitted fifteen to the photo contest...Friday, we went to USF...It was a cool, breezy, sunny day and while we were eating lunch on the Martin Luther King Plaza, Angelo looked up at me with cookie crumbs all over his face and said 'Miss Chantel, I love you!'”. 
Table 5. Member Journal

\begin{tabular}{|c|c|c|c|c|c|}
\hline Experience & Creativity & Teaching & Culture & Community & Frustration \\
\hline $\begin{array}{l}\text { "Long and hard } \\
\text { wonderful"" }\end{array}$ & $\begin{array}{l}\text { "During the mirror } \\
\text { exercises, they had a } \\
\text { blast" }\end{array}$ & $\begin{array}{l}\text { "... children retained } \\
\text { the information" }\end{array}$ & $\begin{array}{l}\text { "Know what the children's } \\
\text { background is, not only } \\
\text { for us but also for }\end{array}$ & $\begin{array}{l}\text { "The Tampa Tribute } \\
\text { Reporter took the } \\
\text { time to interview the }\end{array}$ & $\begin{array}{l}\text { "Far too much construction } \\
\text { going on at my site-limited } \\
\text { space, fresh paint everywhere, }\end{array}$ \\
\hline $\begin{array}{l}\text { "Kids fell asleep } \\
\text {.., but enjoyed the } \\
\text { music by Mahler" }\end{array}$ & $\begin{array}{l}\text { "Work together much } \\
\text { better." }\end{array}$ & $\begin{array}{l}\text { "If lessons are } \\
\text { really structured } \\
\text { and well designed, }\end{array}$ & $\begin{array}{l}\text { themselves to learn that } \\
\text { they all have cultural } \\
\text { background, and to respect }\end{array}$ & $\begin{array}{l}\text { kids and took } \\
\text { information on their } \\
\text { works. The kids were }\end{array}$ & $\begin{array}{l}\text { concrete blocks everywhere, } \\
\text { no table space, no chairs" }\end{array}$ \\
\hline $\begin{array}{l}\text { "Wonderful to see } \\
\text { them enjoying the }\end{array}$ & $\begin{array}{l}\text { "More creative in their } \\
\text { ideas for new }\end{array}$ & $\begin{array}{l}\text { the children will } \\
\text { follow it to the } \\
\text { dot... wish we as a }\end{array}$ & $\begin{array}{l}\text { each other's values and } \\
\text { ethnic background" }\end{array}$ & $\begin{array}{l}\text { very pleased and } \\
\text { happy about it" }\end{array}$ & $\begin{array}{l}\text { "If AmeriCorps had a room, } \\
\text { then she wouldn't have } \\
\text { anything to complain, almost" }\end{array}$ \\
\hline $\begin{array}{l}\text { program" } \\
\text { "learning new }\end{array}$ & $\begin{array}{l}\text { projects...show } \\
\text { interest and respect in } \\
\text { the classroom..." }\end{array}$ & $\begin{array}{l}\text { team could be more } \\
\text { organized", }\end{array}$ & $\begin{array}{l}\text { "The Easter show was a } \\
\text { great opportunity for the } \\
\text { kids at Zonta to see other }\end{array}$ & $\begin{array}{l}\text { "More parents } \\
\text { wanted to know } \\
\text { much more about the }\end{array}$ & $\begin{array}{l}\text { "What do you do when a } \\
\text { student writes on their comic }\end{array}$ \\
\hline skills everyday" & “...gave them control & $\begin{array}{l}\text { "Complement a } \\
\text { child, they usually }\end{array}$ & $\begin{array}{l}\text { kids from a different Boy } \\
\text { and Girls Club and to }\end{array}$ & program" & $\begin{array}{l}\text { strip 'I am not dumb', 'quit } \\
\text { calling me stupid', 'I hate this }\end{array}$ \\
\hline $\begin{array}{l}\text { "Very excited... } \\
\text { well behaved" }\end{array}$ & $\begin{array}{l}\text { and a } \\
\text { sense of challenge", }\end{array}$ & $\begin{array}{l}\text { have instant } \\
\text { interest. If I } \\
\text { accidentally tell }\end{array}$ & $\begin{array}{l}\text { perform for them... } \\
\text { wonderful opportunity for } \\
\text { them to be exposed to a }\end{array}$ & $\begin{array}{l}\text { "When I was a child, } \\
\text { I was a product of a } \\
\text { community where }\end{array}$ & $\begin{array}{l}\text { place', 'I hate going home', 'I } \\
\text { hate everything'.', }\end{array}$ \\
\hline $\begin{array}{l}\text { "Love to come to } \\
\text { art" }\end{array}$ & $\begin{array}{l}\text { "... a sense of } \\
\text { possibilities for } \\
\text { themselves" }\end{array}$ & $\begin{array}{l}\text { them to stop doing } \\
\text { this and that, then } \\
\text { they continue to do }\end{array}$ & $\begin{array}{l}\text { different culture and } \\
\text { different way of celebrating } \\
\text { Easter" }\end{array}$ & $\begin{array}{l}\text { each parent was } \\
\text { parent to every child } \\
\text { in that community }\end{array}$ & $\begin{array}{l}\text { "Stressful week for me... a lot } \\
\text { of work... clean up library } \\
\text { room for exhibition, }\end{array}$ \\
\hline $\begin{array}{l}\text { "Great new } \\
\text { feeling ... projects } \\
\text { are flowing" }\end{array}$ & $\begin{array}{l}\text { “...opportunity to } \\
\text { research for new }\end{array}$ & $\begin{array}{l}\text { it." } \\
\text { "I want focus on }\end{array}$ & $\begin{array}{l}\text { "One of my role models } \\
\text { and mentors was Mrs. Rosa }\end{array}$ & $\begin{array}{l}\text { even to the point of } \\
\text { discipline" }\end{array}$ & $\begin{array}{l}\text { arranging the work properly, } \\
\text { but at the end it was } \\
\text { successful" }\end{array}$ \\
\hline $\begin{array}{l}\text { "Program is } \\
\text { running very } \\
\text { smooth... the kids }\end{array}$ & $\begin{array}{l}\text { answers and } \\
\text { possibilities in } \\
\text { creating art work" }\end{array}$ & $\begin{array}{l}\text { behavior } \\
\text { management as a } \\
\text { priority." }\end{array}$ & $\begin{array}{l}\text { Parks.... When kids insist } \\
\text { that these things did not } \\
\text { happen, I can assure them } \\
\text { that I was there and saw }\end{array}$ & $\begin{array}{l}\text { "Parents were } \\
\text { pleased with the } \\
\text { exhibition" }\end{array}$ & $\begin{array}{l}\text { "We don't have art room, we } \\
\text { worked outside and inside. It } \\
\text { is very cold and raining" }\end{array}$ \\
\hline $\begin{array}{l}\text { love the program } \\
\text { and want more" }\end{array}$ & $\begin{array}{l}\text { "Hands-on projects, } \\
\text { then exposing them to } \\
\text { actually see famous }\end{array}$ & $\begin{array}{l}\text { "Consider a week } \\
\text { of love, not only for } \\
\text { the Boys and Gils, }\end{array}$ & them happen" & & \\
\hline $\begin{array}{l}\text { "Very enthusiastic } \\
\text { and full of ositive } \\
\text { energy" }\end{array}$ & $\begin{array}{l}\text { work of artists really } \\
\text { enforces their } \\
\text { creativity and }\end{array}$ & $\begin{array}{l}\text { but also for } \\
\text { myself..." }\end{array}$ & & & \\
\hline $\begin{array}{l}\text { "....able to express } \\
\text { visually through } \\
\text { the arts." }\end{array}$ & $\begin{array}{l}\text { challenges them even } \\
\text { more... also appreciate } \\
\text { the arts much better" }\end{array}$ & $\begin{array}{l}\text { "...beginning to } \\
\text { appreciate the arts } \\
\text { more... Their } \\
\text { Personal behavior }\end{array}$ & & & \\
\hline $\begin{array}{l}\text { "It's been a } \\
\text { wonderful } \\
\text { experience and a } \\
\text { great } \\
\text { opportunity" }\end{array}$ & $\begin{array}{l}\text { "Positive things in life } \\
\text { and appreciate and } \\
\text { understand other } \\
\text { artists' work ... I can } \\
\text { see many of these } \\
\text { children actually } \\
\text { becoming great } \\
\text { artists." }\end{array}$ & $\begin{array}{l}\text { in some have } \\
\text { changed in a } \\
\text { positive way and } \\
\text { this is very good } \\
\text { and a great feeling } \\
\text { (smile)." }\end{array}$ & & & \\
\hline
\end{tabular}

\subsection{Creativity}

Members used their own imagination to create activities. Shadow drawing, gesture drawing, upside-down drawings, music and dance improvised on children's own poems, making various masks, and wood carving were all part of the program created by the members. Members described the creative process in their daily activity and expressed their delight in seeing the children's response to them. In one class, children were introduced to gesture drawing and making sculpture with their bodies, and they were encouraged to explain how the two activities related to each other. Another member described how she made a pinhole camera and saw children having a great time taking pictures with it. Through improvisation activities integrating music, dance, visual arts, and drama tied on specific themes, members saw the children becoming "more creative in their ideas for new projects," for example, "using dance as a way of opening up to each other," and "gaining control and a sense of the challenge." Members observed the children not only developing problem-solving skills but also learning to work together and sharing the joys of the experience. Making paper mâché with old newspapers and using them for dramatic plays taught teamwork.

Children were encouraged to work on "different medium...create great art work by using found items from the nature and turning them into totally different artistic object." Such creativity gave both the members and children sense of possibilities that they had never thought of before. Seeing their own creations being exhibited at a gallery was inspirational for the children and gave them "a sense of possibilities for themselves of becoming professional artists one day." "These creative experiences also reinforced their appreciation for the arts and about the "positive things in 
life." Members truly believed in the many possibilities of these children's artistic talent. They also taught "courage" through creativity, "Thursday, I read Life doesn't frighten me by Maya Angelou and Jean Michel Basquiat. I read it in a dark closet with a little light and then we created shadow puppets to go with the story."

\subsection{Teaching}

Members wrote in their reflective journals about their development in classroom management, communication, and creative teaching skills. Despite the initial concerns by some of the Executive Council members about the fact that these artists had no previous teacher training, it turned out to be a great joy to watch each member blossom in his or her unique teaching and class management style. The members were developing teaching strategies that involved sequential lesson plans, motivational and positive reinforcements, and behaviour management in their integrated arts lessons. The following member journal entry exemplifies such efforts and growth. "This week I did a complete creative movement lesson. It went extremely well. I reapplied the skills every day and I was excited to see that the children retained the information. We also did a music lesson but it did not go quite as well. I blame that on our preparation, however, not the children. I feel that if we were to tell the children to jump off a bridge, they would. That's how much trust they are developing in us."

At the same time, hands-on experience and reflective time gave members opportunities to test out their life's goals and dreams and also allowed a concrete launching pad for careers, as one Member wrote toward the end of the year about getting an art teaching position, "I got a job! I got a job! I got a job! I'm going to be the art teacher at Cleveland Elementary! It's right by my house! I'm going to have insurance and a salary! Thanks AmeriCorps!"

\subsection{Culture and Diversity}

Members were developing their own sense of broadening diversity in culture and people while teaching and observing the children develop in this area. They were interested in learning about the children's background and saw the value of teaching children awareness and pride in their own cultural background. Each site had its own community culture; and members were learning the cultural diversity by observing children learn to respect the differences: "I feel that the Easter show was a great opportunity for the kids at Zonta to see other kids from a different Boy and Girls Clubs and to perform for them. I think this was a wonderful opportunity for them to be exposed to a different culture and different way of celebrating Easter."

Variety of activities based on strong themes worked well for the members. Teaching children to use different medium to express their feelings gave the members powerful experience to focus on feelings: "This week I consider a week of love, not only for the boys and girls, but also for myself. Valentines made with paper drawings and cut-outs took a back seat to their soap and wood hearts. They were elated with their accomplishments in the soap and wood mediums."

A Member drew on an historical event and his own experience to teach children the value of diversity and human rights: "One of my role models and mentors was Mrs. Rosa Parks. I was a child when Mrs. Parks chose rather to go to jail than to give up her seat on a public bus in Montgomery, Alabama. I experienced many similar situations. When kids insist that these things did not happen, I can assure them that I was there and saw them happen."

\subsection{Community}

One of the program's objectives was developing community interests and engaging the community. This was a tough task for the members at the beginning. Each site had a support group that included Boys and Girls Clubs, parents, performing arts organizations, and the education community that all helped make this program succeed. Building the community and community support came slowly as the program progressed. Many supportive documents including parents' letters, newspaper write-ups, and radio and television appearances helped obtain funding for the subsequent years. A large mural on the side of the Boys and Gils Clubs headquarters stands a proud reminder of the AmeriCorps ArtsUSF to this day. A live performance that dealt with African American celebrations in the production "Bring in 'Da Noise, Bring in 'da Funk" included some of the AmeriCorps ArtsUSF children during their performance at the Tampa Performing Arts Centre. Participation in the Tampa's "First Night" celebration was an exciting venture for both the children and members. Gradually, parents began to show interests in the program. Eventually, Boys and Girls Clubs were able to take over the program with their local supports.

\subsection{Frustration}

Members worked long hours in training and preparing for the program. Once the program began, the children's enthusiasm and delight made it all worthwhile, despite poor facilities and other difficult conditions. The major problem at most of the sites was the space: Even though the site authorities welcomed AmeriCorps ArtsUSF program, their perception of the arts were not much more than extra-curricular crafts time. Our artists' lessons were well 
grounded in the philosophical and theoretical premises of the program to teach children to appreciate the arts and to respect people through the arts activities. Another major issue had to do with children's self-perception. While the members observed change in children during the program, there were still deep-rooted negative self-image. This was reflected in one journal entry: "What do you do when a student writes on [his] comic strip 'I am not dumb,' 'quit calling me stupid,' 'I hate this place,' 'I hate going home,' 'I hate everything."' Despite some of the difficulties and frustrations, the power of sharing humanity through the arts was evident in this program and in the communities.

\section{Discussion}

The conception of this ambitious program began with a question, "What can we do to help lift the lives of our children who are left behind from the American affluence, diversity of culture, and the fine arts?" On a larger premise, we wondered, "Is there a role of the arts toward world peace and globalization?" In this time of political crises around the world, many children are left to learn that hate, crime, and poverty are the norm of life in this world. The AmeriCorp ArtsUSF program was born amid the affluent Tampa Bay area in response to the demands of many pockets of deprived communities. Each site had unique profile of poverty and deprivation: For example, University Park and Recreation site was known as "suite-case city" because of the transient and crime-ridden nature; Zonta site was out in the country where most of the residents were seasonal migrant farm workers. Many of the children who attended the program had never seen the ocean, museum, performing arts centre, university, because there was no one at home who had transportation or time to take them to venture beyond the immediate surrounding. The AmeriCorps ArtsUSF was born partly at the outcry of the citizens who were involved in these children's lives and who valued the arts as the most powerful avenue to touch the young minds and hearts that could ultimately bring about world peace and health. The program had specific curriculum built around these high goals, albeit a step at a time, one person at a time.

The program was able to offer to relatively small classes of children on daily concentrated format by 24 dedicated artists who created unique and outstanding arts programs and touched the lives of over 600 children during the year. What we measured through the survey instruments were but a small fraction of what we saw. Although the instruments were reasonably well structured, administration of the instrument was problematic. Members plunged into working with children, while being continuously trained on teaching and class management as well as interdisciplinary arts methodology on the job. Administering the survey evaluation was a new task to learn for them. Enrolment and attendance managements were done by Boys and Girls Clubs and Park and Recreation site managers, which meant that the members had little control over who were who. It took a while to get to know the children and the logistics of the site. Member evaluation of children's progress, while flawed with possible biases and the inherent problem in recording in time delay, was the best way to assess their progress under the circumstance. Even so, we were pleased that members were conscientious in being as objective as they could. No outside reviewer could possibly know the children well enough to assess those intimate issues addressed in the survey questions.

\section{Limitations}

This report is limited to the first-year data of the AmeriCorp ArtsUSF program which was funded two more years after the initial year. Therefore, the report reveals a snap shot of the first-year operation when the program structure and member training were at the beginning stage and often ran by trial and error. Conversely, the novelty of the program in the communities as well as to the artist-members could have boosted more enthusiasm than sustainable outcomes in the ensuing years. The AAGTD impact data analysis was limited and did not explore in-depth intradimension relationships among the measured skills and attitudes; for example, multiple regression model could have been useful for this purpose.

\section{Conclusion}

AmeriCorps ArtsUSF was an attempt to achieve the high aspiration of world peace and globalization by changing our underserved children's lives and enriching the artist-members' experiences in the micro world around Tampa Bay area. This intense arts experience gives us a hope that the arts can be the conduit to help us realize the need to find mutual understanding among diverse faces; that the arts can help us celebrate the commonalities through appreciation of our differences; that we can use our imagination and tenacity to help pave the way to peace and cooperation among nations; and that with our keen emotional intelligence, artists can help the world dare to think the unthinkable peaceful world and global unity! The new science has explored the anatomy of "amygdala," the feeling part of the brain and has recognized the importance of emotional intelligence in the civilized society [3]. Equally importantly, children's mental health is of the utmost concern for the society throughout the modern world with the shrinking distance and narrowed borders.

Overall, results showed impressive progress in all measured items, particularly integrating arts to life, group problem-solving, attitude on diversity, attitude on being-kind-to-each-other, and alternate skills to aggression. Data 
also showed strong connections between expression through the arts with class learning skills, independent problemsolving skills, ability to integrate arts to life, and positive attitude on diversity. These skills related closely to anti-drug, alcohol, and smoking and attitude toward community. In assessing member progress, journals were filled with thoughtful reflections and much emotional turbulence. Members felt that the AmeriCoprs ArtsUSF provided valuable experience that had profound life-changing impact on them. This was the first time for many of the members to encounter the level of poverty, non-functioning family conditions, and destitute life qualities of the children in these communities. They faced the value and effects of their inputs in helping others through this volunteer experience. They realized that one of the ways of reaching the American dream was by helping the less privileged. Working as the provider gave them confidence and self-esteem necessary to move on to pursue their own life's goals.

For the communities, we left them with pride, uplifted sense of their own capability, many artefacts to remember the program, and tools to carry on to enhancing their lives. The AmeriCorps ArtsUSF governing board has learned the power of the arts in changing the lives of our youth, our member artists' citizenry, and the community. We deeply ponder what if our policy makers were to realize the impact of such community arts programs as compared to the cost of federal and state prison systems. We feel that the program is as relevant today as it was in 1997-98. What we have learned from the study is compelling and applicable particularly in this time of global unrest.

\section{Funding}

The AmeriCorp ArtsUSF program was supported by the following organizations in 1997-1999:

- National Commission on Service

- Florida Commission on Service

- Florida Department of Education

- Tampa Bay Boys and Girls Clubs of Tampa Bay

- Hillsborough County Parks and Recreation

- Phillip Shore Magnet School

- USF Research Foundation

- Coalition for Science Literacy and Suncoast Area Center for Educational Enhancement

- Hillsborough Arts Council

- Florida Department of Education

- Area Center for Educational Enhancement

\section{Declaration of Competing Interest}

The authors declare that they have no known competing financial interests or personal relationships that could have appeared to influence the work reported in this paper.

\section{Ethical Approval}

All ethical protocols and procedures of The AmeriCorps ArtsUSF program were approved by Federal office of the National Service Commission. The Boys and Girls Clubs of Tampa obtained parental consents. The University of South Florida Research Review Board did not require Human Subject Research protocol for this program.

\section{References}

[1] National Endowment for the Arts Report (1988). Toward Civilization: a Report on art Education. Washington, DC: National Endowment for the Arts.

[2] Mahlmann, J. J. (1994). National Standards for Arts Education: What Every Young American Should Know and Be Able To Do in the Arts. Music Educators National Conference Publications Sales, 1806 Robert Fulton Dr., Reston, VA 22091. Available online: https://www2.ed.gov/pubs/ArtsStandards.html (accessed on 18 March 2020).

[3] Goleman, D. (1996). Emotional intelligence. Why it can matter more than IQ. Learning, 24(6), 49-50.

[4] Liao, T. J. (2009). Art Action Programs That Establish Community Cultural Image: Application of “Action Learning” to Art Curriculum Programs in Liberal Education In Universities. Jiaoyu Kexue Yanjiu Qikan, 54(2), 163. doi: 10.3966/2073753X2009065402007. Published in Taiwan. 
[5] Elliott, L., \& Clancy, S. (2017). Ripples of Learning: A Culturally Inclusive Community Integrated Art Education Program. Art Education, 70(6), 20-27. doi:10.1080/00043125.2017.1361766.

[6] McKeown, E., Weir, H., Berridge, E.-J., Ellis, L., \& Kyratsis, Y. (2016). Art engagement and mental health: experiences of service users of a community-based arts programme at Tate Modern, London. Public Health, 130, 29-35. doi:10.1016/j.puhe.2015.09.009.

[7] Kelly, J. D., Frankfurter, R., Lurton, G., Conteh, S., Empson, S. F., Daboh, F., .. Barrie, M. B. (2018). Evaluation of a community-based ART programme after tapering home visits in rural Sierra Leone: a 24-month retrospective study. SAHARAJ: Journal of Social Aspects of HIV/AIDS, 15(1), 138-145. doi:10.1080/17290376.2018.1527244.

[8] Richerson, J., Pendleton, A., \& Davis, D. W. (2016). A Community Arts-Based Parent Program. Clinical Pediatrics, 56(12), 1135-1141. doi:10.1177/0009922816678819.

[9] Wright, R., John, L., Alaggia, R., Duku, E., \& Morton, T. (2019). Do Community Arts Programs Promote Positive Youth Development? Critical Social Work, 9(1). doi:10.22329/csw.v9i1.5763.

[10] Wright, R., Alaggia, R., \& Krygsman, A. (2014). Five-year follow-up study of the qualitative experiences of youth in an afterschool arts program in low-income communities. Journal of Social Service Research, 40(2), 137-146.

[11] Cole, R., Gordon, B., Kayser, A., \& Caruccio, J. (2017). Creating Artists and Citizens: Teaching Community through an ArtsBased Mentoring Program. Transformations: The Journal of Inclusive Scholarship and Pedagogy, 27(1), 77-86.

[12] Ngo, B., Lewis, C., \& Maloney Leaf, B. (2017). Fostering Sociopolitical Consciousness With Minoritized Youth: Insights From Community-Based Arts Programs. Review of Research in Education, 41(1), 358-380. doi:10.3102/0091732x17690122.

[13] The Consortium of National Arts Education Associations: AATE, MENC, NAEA, NDEO (2002). Authentic Connections: Interdisciplinary Work in the Arts.

[14] AmeriCorps Brochure 2019_WebVersion. Available online: https://www.nationalservice.gov/sites/default/files/documents/ AmeriCorps\%20Brochure\%202019_WebVersion.pdf.

[15] AmeriCorps ArtsUSF. (1998) Integrated Arts for Boys and Girls. Tampa, Florida: Kinkos Copies, Inc.

[16] Lee, Sang-Hie, (1998) AmeriCorps ArtsUSF Assessment Instrument Getting Things Done (AAGTD).

[17] McGinnis, Ellen and Arnold P. Goldstein with Robert P. Sprafkin \& N.Jane Gershaw, (1984) Skill-Streaming the Elementary School Child: A Guide for Teaching Prosocial Skills. Champaign, Illinois: Research Press Company.

[18] Lincoln, Y.S. and Guba, E.G., (1995) Natural Inquiry. Beverly Hills, CA: Sage Publications.

[19] Miles, M. B., \& Huberman, A. M. (1984). Qualitative data analysis: A sourcebook of new methods. In Qualitative data analysis: a sourcebook of new methods. Sage publications.

[20] Creswell, J.W., Goodchild, L.F., and Turner, P.P., (1996) Integrated Qualitative and Quantitative Research: Epistemology, History, and Design. In John C. Smart (ed): Higher Education Handbook of Theory and Research, Volume XI. New York: Agathon Press, pp.90-136. 


\section{Appendix I}

AmeriCorps ArtsUSF Assessment Instrument

Getting Things Done (AAGTD)

Student's Name

School

[V 3]
Evaluator: Member or Outside Observer

Age

[V 2]

Program Site

Date

Person Responsible for Assessment Introduction: This instrument is designed to assess the impact of AmeriCorps ArtsUSF program on children's development of arts
and arts-related skills, classroom learning skills, and cultural behavior and attitude. Section I contains four dimensions to measure arts and arts-related skill; Section II, three dimensions on classroom learning skills; and Section III, five dimensions relating to cultural behavior and attitude.

\section{Section I: Arts and Arts-Related Skills}

\section{Arts Skills}

a) Uses appropriate body movement and coordination in various movement phrases

b) Transfers rhythmic patterns from the aural to the kinesthetic

c) Uses improvisation to solve movement problems and adjusts choices

d) Creates simple rhythm patterns

e) Answers to a given melody with a simple tune

f) Creates simple scenes that have a setting, dialogue, and plot

\section{Expressive Skills through the Arts}

a) Creates arts patterns that convey ideas, thoughts, or feelings

b) Expresses remembered ideas, feelings, and concepts of common daily activities through art forms

c) Uses new skills or ideas in the class

Arts Appreciation Skills

a) Expresses emotions through dramatic art, music, dance, and visual art

b) Knows how concepts such as shape, line, sequence, space and time are related among art, music, dance, and drama

c) Knows how we learn about ourselves, our relationships, and our environment through art forms

d) Knows how artists generate and express ideas according to their individual, cultural, and historical experiences

\section{Integrating Arts to Life}

a) Knows how arts are related to other subjects (e.g., how a) vibrations produce musical sounds)

b) Knows the uniqueness of art and its importance in society (e.g., public and private rituals)

c) Knows how societal conditions relate to artists and arts

d) Knows how arts can communicate ideas feelings, moods, or images

e) Uses role playing to resolve everyday conflict situations

f) Knows that people create arts for various reasons

g) Knows various careers that are available to artists
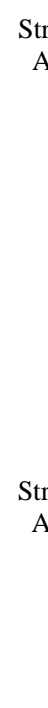

Stro

Strongly Agree

5

5

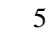

Strongly Agree

Agree

4

4

4

4

Agree

4

4

4

4

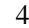

4
Agree

Not Sure

4

Agree

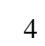

5

5

5

4

4
4
4
4
4
4
4

$\begin{array}{ll}\text { Disagree } & \text { Strongly } \\ & \text { Disagree }\end{array}$

$\begin{array}{ll}2 & 1 \\ 2 & 1 \\ 2 & 1 \\ 2 & 1 \\ 2 & 1 \\ 2 & 1\end{array}$

[V 5]

$3 \quad 2$ 


\section{Section II. Learning Skills}

Classroom Learning Skills

a) Pays attention during class

b) Raises hand when the teacher asks questions to class

c) Speaks up with ideas that contribute to the questions

d) Seems focused when presented with new skills or ideas

Independent Problem-Solving Skills

a) Delves into the situation when given new tasks

b) Handles well when given challenging tasks

Group Problem-Solving Skills

a) Likes being in the group

b) Participates in the group discussion

c) Shares thoughts in the group

$\begin{array}{cccccc}\begin{array}{c}\text { Strongly } \\ \text { Agree }\end{array} & \text { Agree } & \text { Not Sure } & \text { Disagree } & \begin{array}{c}\text { Strongly } \\ \text { Disagree }\end{array} \\ 5 & 4 & 3 & 2 & 1 & \text { [V 25] } \\ 5 & 4 & 3 & 2 & 1 & \text { [V 26] } \\ 5 & 4 & 3 & 2 & 1 & \text { [V 27] } \\ 5 & 4 & 3 & 2 & 1 & \text { [V 28] } \\ & & & & & \\ \text { Strongly } & \text { Agree } & \text { Not Sure } & \text { Disagree } & \text { Strongly } & \\ \text { Agree } & 4 & 3 & 2 & 1 & \text { [V 29] } \\ 5 & 4 & 3 & 2 & 1 & \text { [V 30] } \\ 5 & & & & \text { Strongly } & \\ \text { Strongly } & \text { Agree } & \text { Not Sure } & \text { Disagree } & \text { Disagree } & \\ \text { Agree } & 4 & 3 & 2 & 1 & \text { [V 31] } \\ 5 & 4 & 3 & 2 & 1 & \text { [V 32] } \\ 5 & 4 & 3 & 2 & 1 & \\ 5 & & & & & \end{array}$

\section{Section III. Cultural Behavior and Attitude}

Diversity of Culture and People

a) Opens up to new people easily

b) Opens up to new and different things easily

c) Asks questions about new and different people and things

\section{Being Kind-to-each-other}
a) Is friendly to friends
b) Is friendly to new faces
c) Shares things with others
d) Shows kindness toward others with no reason at all

Attitude about Drugs, Alcohol, and Smoking

a) Expresses his/her feelings about drugs, alcohol, and
smoking
b) Shows evidence that he/she is against these problems

Attitude about Community

a) Expresses feelings about community

b) Shows interest in doing something for the community
Strongly Agree$$
5
$$$$
5
$$

Strongly Agree

5

\section{5}

5

5

Strongly Agree

$$
5
$$$$
5
$$

Strongly Agree

$\begin{array}{cc}\text { Agree } & \text { Not Sure } \\ 4 & 3 \\ 4 & 3 \\ 4 & 3\end{array}$

Agree Not Sure

\section{$\begin{array}{ll}\text { Disagree } & \begin{array}{l}\text { Strongly } \\ \text { Disagree }\end{array}\end{array}$}

1

1

1

[V 34]

[V 35]

[V 36]

2

$\begin{array}{ll}\text { Disagree } & \text { Strongly } \\ \text { Disagree }\end{array}$

[V 37]

[V 38]

[V 39]

[V 40]

1

Strongly Disagree

$$
1
$$

$$
1
$$

Strongly Disagree 